\title{
Akta Peralihan Harta Pailit Berupa Benda Tetap Yang Dijual Tanpa Lelang Oleh Kurator
}

\section{Yasser Al Mursyid}

Magister Kenotariatan Fakultas Hukum Universitas Islam Indonesia Yogyakarta Indonesia Jln. Cik Di Tiro No. 1 Yogyakarta Indonesia umdosen@gmail.comsseralmursyid@gmail.com

Key Word: $\begin{aligned} & \text { Abstract } \\ & \text { Bankruptcy Law, } \\ & \begin{array}{l}\text { PPAT, transfer of } \\ \text { deed }\end{array} \\ & \text { objects which are sold without auction by the Curator. The problem formulated in } \\ & \text { this research is first, why there is a transfer of bankrupt assets in the form of fixed } \\ & \text { objects that are sold without an auction by the Curator. Second, how is the authority } \\ & \text { and responsibility of PPAT for the deed of transfer of bankrupt assets in the form of } \\ & \text { fixed objects that are sold without an auction by the Curator. This research is } \\ & \text { normative with a statutory and a conceptual approaches. The results of the study } \\ & \text { conclude that first, that there are various problems that arise from the existence of } \\ & \text { an auction selling mechanism that disrupts the independence of the curator so that } \\ & \text { the curator prefers to sell under hands. Second, PPAT's responsibility when } \\ & \text { associated with his profession adheres to the principle of error responsibility so that } \\ & \text { in making an authentic deed, PPAT must be responsible if there is an error or } \\ & \text { violation of the deed he made }\end{aligned}$

\section{Kata-kata Kunci: $\quad$ Abstrak}

PPAT, Akta Penelitian ini meneliti tentang akta peralihan harta pailit berupa benda tetap Peralihan, Hukum yang dijual tanpa lelang oleh Kurator. Masalah yang dirumuskan dalam Kepailitan penelitian ini pertama, mengapa terjadi peralihan harta pailit berupa benda tetap yang dijual tanpa lelang oleh Kurator. Kedua, bagaimana wewenang dan tanggung jawab PPAT atas akta peralihan harta pailit berupa benda tetap yang dijual tanpa lelang oleh Kurator. Penelitian ini secara normatif dengan pendekatan perundang-undangan dan pendekatan konseptual. Hasil penelitian menyimpulkan, pertama, berbagai masalah yang timbul dari adanya mekanisme penjualan secara lelang yang menyebabkan terganggunya independensi Kurator sehingga Kurator lebih memilih penjualan secara di bawah tangan. Kedua, Tanggungjawab PPAT apabila dikaitkan dengan profesinya menganut prinsip tanggungjawab kesalahan sehingga dalam pembuatan akta otentik, PPAT harus bertanggungjawab apabila terjadi kesalahan atau pelanggaran terhadap akta yang dibuatnya

\section{Pendahuluan}

Keberadaan Pejabat Pembuat Akta Tanah (untuk selanjutnya disingkat PPAT) dilandasi oleh kebutuhan masyarakat dalam pembuatan akta otentik dalam peralihan hak atas tanah dan hak milik atas satuan rumah susun sebagai suatu alat bukti yang sempurna dan mengikat. Masyarakat dalam memenuhi kebutuhan dan kepentingannya selalu berkaitan erat dengan hukum baik secara langsung maupun tidak langsung. Sehingga perlu ada parameter dalam melakukan tindakan hukum, menerapkan hukum, hingga penegakkan hukum agar tercapai kepastian hukum. ${ }^{1}$

\footnotetext{
${ }_{1}^{1}$ Abdul Hakim G. Nusantara, Politik Hukum Indonesia, Yayasan Lbh Indonesia, Jakarta, 1998, hlm. 70.
} 
Akta yang diterbitkan oleh seorang PPAT memberikan jaminan kepastian hukum bagi masyarakat khususnya kepada pihak-pihak yang berkepentingan di dalam akta tersebut. PPAT merupakan salah satu profesi hukum yang memiliki peran penting dalam mengimplementasikan fungsi hukum itu sendiri.

Akta-akta yang dibuat oleh Notaris dan/atau PPAT erat kaitannya dengan perbuatan hukum yang dilakukan oleh masyarakat terutama dalam hal atau tindakan masyarakat satu dengan lainnya yang dapat melahirkan hak dan kewajiban yang dituangkan dalam bentuk akta, misalnya dalam hal utang piutang dimana untuk mempertegas kedudukan para pihak maka dibuat akta perjanjian utang piutang. Manusia sebagai mahluk sosial akan senantiasa melakukan hubungan hukum untuk memenuhi kebutuhan hidupnya ${ }^{2}$. Pemberian utang atau kredit oleh kreditor dalam kedudukannya sebagai orang perseorangan maupun badan hukum kepada debitor, sudah lazim terjadi dalam kehidupan masyarakat. Sehingga dewasa ini para pengusaha lazim menggunakan fasilitas hutang (penjaman atau kredi), sebagai faktor yang melekat dalam dunia ekonomi, bisnis dan perdagangan. ${ }^{3}$

Meskipun demikian, praktik hutang oleh para pengusaha juga memiliki resiko permasalahan hutang piutang. Terdapat beberapa cara yang dapat digunakan untuk menyelesaikan masalah utang piutang secara hukum, antara lain melalui perdamaian, penyelesaian sengketa alternatif, serta penundaan kewajiban pembayaran utang dan kepailitan. Dari beberapa cara tersebut, salah satu yang paling umum dan cukup banyak digunakan dalam penyelesaian utang yaitu kepailitan. Kepailitan dipilih sebebagai cara penyelesaian sengketa piutang yang menjamin keamanan dan kepentingan para pihak, karena Lembaga Kepailitan melibatkan instansi-instansi yang mengemban tugas resmi dari pemerintah, seperti Pengadilan Niaga, Hakim Pengawas, dan Kurator. ${ }^{4}$

Kepailitan diartikan sebagai keadaan debitur (yang berutang) yang berhenti membayar (tidak membayar) utang-utangnya. ${ }^{5}$ Ketentuan mengenai kepailitan di Indonesia diatur dalam Undang-Undang Nomor 37 Tahun 2004 Tentang Kepailitan dan Penundaan Kewajiban Pembayaran Utang (selanjutnya disebut Undang-Undang Nomor 37 Tahun 2004). Berdasarkan Pasal 1 Angka 1 Undang-Undang Nomor 37 Tahun 2004, Kepailitan adalah sita umum atas semua kekayaan Debitur Pailit yang pengurusan dan pemberesannya dilakukan oleh Kurator di bawah pengawasan Hakim Pengawas.

Setelah dinyatakan pailit oleh pengadilan, maka status hukum debitur terkait kecakapannya untuk menguasai serta mengurus harta kekayaannya dialihkan kepada Kurator. Tugas Kurator, sebagaimana diatur dalam Pasal 16 ayat (1) Undang-Undang Nomor 37 Tahun 2004, diantaranya melakukan pemberesan terhadap aset debitur, termasuk dalam melakukan penjualan aset debitur sehingga akan diperoleh uang untuk menyelesaikan utang debitur terhadap para krediturnya.

\footnotetext{
2 Satjipto Rahardjo, Ilmu Hukum, Cet. 7, Citra Aditya Bakti, Bandung, 2012, hlm. 125.

${ }^{3}$ Ivida Dewi Amrih Suci Dan Herowati Poesoko, Hukum Kepailitan, Kedudukan Kreditor Separatis Atas Benda Jaminan Debitor Pailit, Laksbang Pressindo, Yogyakarta, 2016, hlm. 1.

${ }^{4}$ Man S. Sastrawidjaja, Hukum Kepailitan Dan Penundaan Kewajiban Pembayaran Utang, Alumni, Bandung, 2006, Hlm. 2

${ }_{5}$ Zainal Asikin, Hukum Kepailitan Dan Penundaan Pembayaran Di Indonesia, Raja Grafindo Persada, Jakarta, 2001, hlm. 27.
} 
Proses penjualan harta debitor yang dinyatakan pailit, dilakukan oleh kurator dengan dua cara yaitu penjualan di muka umum dengan mekanisme lelang dan penjualan di bawah tangan. Berdasarkan ketentuan Pasal 185 Undang-Undang Nomor 37 Tahun 2004 menyatakan sebagai berikut:

1. Semua benda harus dijual di muka umum sesuai dengan tata cara yang ditentukan dalam peraturan perundang-undangan.

2. Dalam hal penjualan di muka umum sebagaimana dimaksud pada ayat (1) tidak tercapai maka penjualan di bawah tangan dapat dilakukan dengan izin Hakim Pengawas.

Dalam perkembangannya, proses penjualan harta pailit oleh Kurator terdapat penyimpangan terhadap ketentuan Pasal 185 ayat (1) dan Ketentuan Pasal 185 ayat (2) dimana terjadi penggabungan kedua Pasal tersebut ke dalam satu penetapan yakni dalam Penetapan Nomor 44/PKPU/2012/PN.Niaga.Jkt.Pst., tanggal 01 April 2013 sebagaimana tertuang di dalam butir 2 Penetapan yakni:

"2. Mengizinkan Kurator PT. Jaya Nur Sukses (Dalam Pailit) melakukan pemberesan dengan cara penjualan di muka umum (lelang) atau penjualan tidak dimuka umum (di bawah tangan/ Notarial) atas seluruh harta pailit milik PT. Jaya Nur, Sukses (Dalam Pailit), dengan tunduk pada syarat dan ketentuan sebagaimana dimaksud dalam Pasal 185 ayat (I) ayat (2) Undang-Undang No. 37 Tahun 2004 tentang Kepailitan dan Penundaan Kewajiban Pembayaran Utang".

Bahwa dengan digunakannya dalil "atau" maka hal ini dapat berpotensi pada perbuatan hukum yang dapat dilakukan oleh Kurator dalam hal melakukan pemberesan atas boedel pailit melalui mekanisme penjualan di bawah tangan. Dengan digunakannya dalil "atau" maka kurator dapat memilih antara penjualan secara lelang atau penjualan secara bawah tangan atas boedel pailit debitor. Kemudian, dengan bunyi penetapan yang demikian itu memberikan peluang bagi kurator untuk melakukan penjualan terhadap boedel debitor pailit tanpa mekanisme lelang terlebih dahulu karena dalam penetapan tersebut Hakim Pengawas mengijinkan kurator PT. Jaya Nur Sukses (Dalam Pailit) melakukan pemberesan dengan cara penjualan di muka umum (lelang) atau penjualan tidak di muka umum (di bawah tangan/Notarial) atas seluruh harta pailit milik PT. Jaya Nur Sukses, dan dengan adanya penetapan ini maka kurator dimungkinkan untuk memilih mekanisme penjualan atas boedel pailit debitor.

Mengenai dalam hal penjualan boedel pailit secara bawah tangan maka tugas seorang Kurator tidak dapat dilakukan sendiri, terutama untuk mengalihkan boedel pailit berupa benda tetap (tanah) tentunya akan berhubungan dengan pejabat yang diberi kewenangan oleh negara untuk proses pembuatan akta pelepasan hak. Dalam hal ini peran tersebut dimiliki oleh seorang PPAT. Mekanisme penjualan harta tidak bergerak untuk memenuhi ketentuan Peraturan Perundang-Undangan mengenai peralihan hak atas tanah dan bangunan, Kurator memerlukan kewenangan PPAT untuk menerbitkan Akta Jual Beli yang nantinya dapat dijadikan oleh pihak ketiga (pembeli) dalam proses balik nama.

Implementasi ketentuan Pasal 185 ayat (2) Undang-Undang No. 37 Tahun 2004, jelas menyalahi ketentuan Pasal 185 ayat (1) Undang-Undang No. 37 Tahun 2004, karena 
penjualan secara bawah tangan tidak dapat dilakukan apabila penjualan melalui mekanisme lelang belum dilaksanakan. Bahwa berdasarkan ketentuan Pasal 185 ayat (1) Undang-Undang No. 37 Tahun 2004, yang menyatakan bahwa: "semua benda harus dijual di muka umum sesuai dengan tata cara yang ditentukan dalam peraturan perundang-undangan". Bahwa dengan didasarkan atas ketentuan Pasal tersebut maka, dalam proses pemberesan khususnya dalam penjualan harta pailit berupa benda tidak bergerak kepada pihak ketiga harus terlebih dahulu melalui mekanisme lelang sebelum dilakukan secara di bawah tangan.

Berdasarkan uraian-uraian tersebut di atas dengan didasarkan pada teori dan konsep penjualan boedel pailit oleh Kurator, khususnya terhadap benda tidak bergerak dengan adanya penggabungan terhadap Ketentuan Pasal 185 ayat (1) dan Pasal 185 ayat (2) Undang-Undang No. 37 Tahun 2004, sebagaimana tertuang dalam Penetapan Nomor 44/PKPU/2012/PN. Niaga.Jkt.Pst., tanggal 01 April 2013, maka terkait dengan permasalahan hukum tersebut, penulis ingin meneliti penyebab terjadinya penjualan harta pailit oleh Kurator secara di bawah tangan serta peran dari seorang PPAT dalam pembuatan akta peralihan hak atas benda tetap terhadap harta pailit.

\section{Rumusan Masalah}

1. Mengapa terjadi peralihan harta pailit berupa benda tetap yang dijual tanpa lelang oleh Kurator?

2. Bagaimana wewenang dan tanggung jawab PPAT atas Akta Peralihan Harta Pailit berupa benda tetap yang dijual tanpa lelang oleh Kurator?

\section{Tujuan Penelitian}

1. Menganalisis penyebab terjadinya peralihan harta pailit berupa benda tetap yang dijual tanpa lelang oleh kurator.

2. Menganalisis wewenang dan tanggung jawab PPAT atas Akta Peralihan Harta Pailit berupa benda tetap yang dijual tanpa lelang oleh Kurator.

\section{Metode Penelitian}

Pada metode penelitian ini, peneliti memaparkan jenis penelitian normatif, metode pendekatan yang digunakan adalah perundang-undangan dan konseptual. Untuk sumber data, peneliti menggunakan bahan hukum primer, sekunder dan tersier. Sedangkan cara pengambilan data dalam penelitian ini guna untuk memperoleh bahan hukum yang diperlukan, maka digunakan teknik pengumpulan bahan hukum tersebut dengan penelitian kepustakaan dan juga teknik analisis data dengan menggunakan metode preskriptif yang memberikan penilaian (justifikasi) tentang obyek yang diteliti apakah benar atau salah, atau apa yang seyogyanya menurut hukum. 


\section{Hasil Penelitian dan Pembahasan}

\section{Peralihan Harta Pailit berupa Benda Tetap yang Dijual Tanpa Lelang oleh Kurator}

Peralihan harta pailit yang dilakukan oleh seorang kurator dalam pemberesan boedel pailit yang dimaksud adalah perbuatan hukum yang bertujuan memindahkan hak milik kepada orang lain (Yuridiche Levering). Dalam penjualan boedel pailit oleh Kurator dilaksanakan dengan dua cara, yaitu melalui penjualan secara umum dan di bawah tangan. Hal ini berdasarkan Pasal 185 ayat (1) dan ayat (2) Undang-Undang No. 37 Tahun 2004 yang menyatakan bahwa (1) Semua benda harus dijual di muka umum sesuai dengan tata cara yang ditentukan dalam peraturan perundang-undangan. (2) Dalam hal penjualan di muka umum sebagaimana dimaksud pada ayat (1); tidak tercapai, maka penjualan di bawah tangan dapat dilakukan dengan izin hakim pengawas.

Kurator tidak memerlukan persetujuan debitor dalam memulai pemberesan dan menjual semua harta pailit apabila dalam rapat pencocokan piutang tidak ditawarkan rencana perdamaian oleh debitor, rencana perdamaian yang ditawarkan tidak diterima, atau pengesahan perdamaian ditolak berdasarkan putusan yang telah memperoleh kekuatan hukum tetap. Keadaan tersebut mengakibatkan status harta pailit berada dalam keadaan insolvensib oleh karena itu, kurator harus memulai pemberesan dan menjual semua harta pailit tanpa perlu memperoleh persetujuan atau bantuan debitur.

Dalam proses penjualan harta pailit berupa benda tetap oleh Kurator, tentunya terdapat berbagai kondisi yang mempengaruhi independensi seorang kurator. Penjualan harta pailit yang dilakukan secara di muka umum dalam pelaksanaannya terdapat berbagai kondisi yang menyebabkan terganggunya sifat ketidakberpihakan seorang Kurator dalam pelaksanaan proses pemberesan harta yang termasuk dalam boedel pailit. Terutama dalam pemenuhan prinsip keterbukaan sehingga penjualan tersebut tidak terselubung dan dapat dipertanggung jawabkan. Adapun berbagai faktor atau permasalahan yang dapat mempengaruhi independensi seorang Kurator adalah sebagai berikut:

Pertama, proses penjualan harta pailit melalui lelang memiliki mekanisme penilaian, penaksiran dan pengumuman. Hal ini menyebabkan biaya yang mahal dan berpengaruh terhadap harta pailit. Terlebih apabila terjadi kegagalan dalam proses lelang pertama yang menyebabkan proses lelang perlu untuk diulang kembali sehingga biaya yang harus dikeluarkan menjadi bertambah. Kondisi ini dapat berpotensi menimbulkan pembengkakan biaya dikarenakan Undang-Undang No. 37 Tahun 2004 tidak memberikan batas berapa kali proses penjualan di muka umum dapat dilakukan. Dengan tidak adanya batasan dalam proses penjualan harta pailit secara lelang mengakibatkan Kurator dapat segera melaksanakan proses penjualan harta pailit secara di bawah tangan dengan tujuan agar proses pemberesan harta pailit dilakukan secepat mungkin dengan biaya yang rendah.

6 Pasal 178 ayat (1) Undang-Undang No. 37 Tahun 2004, Insolvensi Adalah Keadaan Debitor Tidak Mampu Membayar. 
Kedua, selain adanya faktor mahalnya proses penjualan di muka umum, faktor appraisal $^{7}$ menjadi permasalahan dalam proses penjualan dengan mekanisme lelang dimana proses appraisal yang dilakukan sebelum penjualan di muka umum sulit dijadikan patokan harga penjualan barang karena seringkali hasil appraisal berbeda jauh dengan penawaran di lapangan. ${ }^{8}$ Kondisi ini mengakibatkan harta pailit yang dijual melalui mekanisme lelang sulit untuk terjual.

Hal ini ditambah kurangnya peran penilai (appariser) dalam menentukan harga objek lelang, Dalam penentuan harga lelang sepenuhnya dilakukan oleh Kurator yang bertindak sebagai kreditur (penjual) dan bukan wewenang Penilai untuk menentukan Harga Lelang. Penilai hanya sebatas memberikan Opini Nilai Pasar dan Nilai Likuidasi saja atas aset yang akan dilelang9. Penentuan nilai limit harga jual obyek lelang ditetapkan oleh pemohon lelang (Kurator), sedangkan Kantor Pelayanan Kekayaan Negara dan Lelang (KPKNL) hanya sebatas melelang obyek dengan nilai limit yang telah ditetapkan oleh pemohon lelang dan tidak ikut terlibat dalam penentuan nilai limit tersebut.

Ketiga, dari skema penjualan harta pailit dengan mekanisme lelang yang diatur dalam Undang-Undang No. 37 Tahun 2004 terlihat bahwa peran hakim pengawas sangatlah pasif, dimana peran hakim pengawas hanya menerima laporan penjualan dari kurator. Apabila ditemukan kejanggalan dalam proses lelang maka sangat sulit bagi hakim pengawas untuk melakukan tindakan pada kurator apalagi jika tidak ada laporan dari kreditor maupun debitor. Salah satu kejanggalan yang ditemukan dalam proses lelang adalah sulitnya harta terjual dalam proses lelang padahal kondisi aset sangat marketable. ${ }^{10}$

Dalam pelaksanaan penjualan benda tetap yang termasuk dalam boedel pailit yang memerlukan adanya ijin hakim pengawas, menjadikan hakim pengawas harus melihat apakah tindakan tersebut menguntungkan harta pailit atau tidak. Adanya kemungkinan yang cukup besar karena harus melakukan tindakan yang cepat maka kurator tidak sempat untuk meminta persetujuan hakim pengawas atas tindakannya. Jadi dalam hal ini hakim pengawas harus melihat tujuan dan hasil dari tindakan tersebut, apakah menguntungkan bagi harta pailit atau tidak.

Keempat, jika melihat alur kepailitan terhadap suatu perusahaan, Kurator dapat melakukan pemberesan harta Debitor pailit setelah adanya putusan pailit yang dikeluarkan oleh Pengadilan Niaga. Dalam Putusan Pailit tersebut harus memuat ketentuan eksekutorial yang mengijinkan Kurator untuk melakukan pemberesan boedel pailit, salah satunya ketentuan mengenai mekanisme penjualan harta pailit. Putusan Pailit tersebut dapat menjadi masalah jika tidak mengacu pada Undang-Undang No. 37 Tahun 2004, terutama dalam Terutama dalam perumusan frasa mengenai penentuan mekanisme penjualan boedel pailit baik terhadap harta bergerak maupun tidak bergerak.

${ }^{7}$ Appraisal Adalah Proses Analisa Yang Dilakukan Oleh Profesional Berupa Penaksiran Nilai Sebuah Benda Nyata.

8 Luthvi Febryka Nola, "Mafia Kepailitan Dalam Penjualan Harta Pailit”, Jurnal Kajian Vol. 23 No. 3 September 2018, Pusat Penelitian Badan Keahlian DPR RI, hlm. 215.

${ }^{9}$ Mohamad Faiz Nasrulloh, "Perlindungan Hukum Bagi Debitur Dalam Penentuan Harga Obyek Lelang Sepihak Yang Dilaksanakan Di Kantor Pelayanan Kekayaan Negara Dan Lelang (KPKNL) Kota Semarang”, Skipsi Fakultas Syariah Dan Hukum Universitas Islam Negeri Walisongo Semarang, 2020, hlm. 58.

${ }^{10}$ Op. Cit., Luthvi Febryka Nola, hlm. 216. 
Sebagaimana yang terdapat dalam Penetapan Nomor 44/PKPU/2012/PN. Niaga.Jkt.Pst., tanggal 01 April 2013 dimana terjadi penggunaan kata "atau" yang menyebabkan Kurator dapat memilih antara penjualan secara lelang atau penjualan secara bawah tangan atas boedel pailit debitor. Tentunya jika mengacu Pada Pasal 185 Undang-Undang Nomor 37 Tahun 2004 mekanisme penjualan boedel pailit dilakukan dengan mekanisme penjualan di muka umum terlebih dahulu, selanjutnya jika penjualan di muka umum tidak tercapai Kurator dapat melakukan penjualan secara di bawah tangan atas ijin Hakim Pengawas. Perbedaan penafsiran dalam penggunaan dalil "atau" tentunya dapat membuat seorang Kurator lebih memilih penjualan secara di bawah tangan dibandingkan dengan penjualan di muka umum. Karena seorang Kurator dalam melakukan pemberesan boedel pailit tentunya dilakukan dengan dasar hukum atau alas hak dalam suatu penetapan yang tentunya harus sesuai dengan ketentuan Pasal 185 Undang-Undang Nomor 37 Tahun 2004.

\section{Wewenang dan Tanggungjawab PPAT atas Akta Peralihan Harta Pailit Berupa Benda Tetap yang Dijual Tanpa Lelang oleh Kurator}

Merujuk pada aspek formil dalam peralihan harta pailit hak terhadap benda tetap atau tidak bergerak termasuk tanah, pesawat, dan kapal laut dengan bobot lebih dari 20 $\mathrm{M}^{3}$ memerlukan proses peralihan benda tetap yaitu dengan Akta Jual Beli. Sehingga PPAT dalam hal ini memiliki kewenangan dan bertindak sebagai pejabat yang berwenang dalam membuat Akta Jual Beli dalam peralihan harta pailit. Penjualan terhadap benda tidak bergerak secara di bawah tangan yang dilakukan dengan pembuatan Akta Jual Beli oleh PPAT dilaksanakan dengan ketentuan bahwa jual beli tersebut harus dihadiri oleh para pihak, dalam hal ini adalah pihak pembeli dan penjual, dan apabila terdapat salah satu pihak yang tidak dapat hadir, harus menyertakan surat kuasa yang telah dijelaskan sebelumnya. Namun, di dalam Pasal 185 ayat (2) UndangUndang No. 37 Tahun 2004 tidak mensyaratkan pemilik barang tidak bergerak untuk hadir dalam penjualan di bawah tangan tersebut dan tidak ada ketentuan yang menyatakan bahwa terdapat kuasa menjual karena berdasarkan ketentuan Pasal 69 ayat (1) dan (2) kurator dalam melakukan pemberesan terhadap harta debitor yang termasuk dalam boedel pailit tidak memerlukan adanya persetujuan dari debitor terlebih dahulu.

Apabila telah terpenuhi syarat sah perjanjian, maka para pihak baik penjual dan pembeli bersama-sama menghadap kepada PPAT yang wilayah kerjanya berada di lokasi benda tidak bergerak yang dijual. Dengan ditandatanganinya Akta Jual Beli terhadap benda tidak bergerak yang termasuk ke dalam boedel pailit oleh para pihak di hadapan PPAT maka peralihan terhadap benda tidak bergerak tersebut telah sah secara hukum. ${ }^{11}$

PPAT juga memikul tanggungjawab dalam memberikan perlindungan hukum kepada para pihak ketika PPAT melakukan perbuatan yang melanggar hukum dalam melaksanakan tugas jabatannya, sehingga menyebabkan kerugian bagi para pihak yang meminta jasa pelayanannya. Bentuk tanggungjawab PPAT apabila dikaitkan dengan profesinya menganut prinsip tanggungjawab kesalahan (based on fault of liability). Sehingga dalam pembuatan akta otentik, PPAT harus bertanggungjawab apabila terjadi

\footnotetext{
${ }^{11}$ Pasal 37 ayat (1) Peraturan Pemerintah Nomor 24 Tahun 1997 tentang Pendaftaran Tanah.
} 
kesalahan atau pelanggaran terhadap akta yang dibuatnya. Akan tetapi apabila unsur kesalahan atau pelanggaran dilakukan oleh para pihak, maka PPAT yang bersangkutan tidak dapat diminta pertanggung jawabannya, karena PPAT hanya mencatat apa yang disampaikan oleh para pihak atau penghadap untuk dituangkan ke dalam akta. Begitu pula apabila para pihak menyampaikan keterangan palsu maka pertanggung Jawaban menjadi beban dari para pihak, bukan pada PPAT.

Mengenai berbagai jenis tanggung jawab PPAT dalam pelaksanaan tugas dan jabatannya yang dalam hal ini adalah pembuatan Akta Peralihan Benda Tetap/tidak bergerak atas harta pailit, PPAT memiliki dua macam bentuk pertanggungjawaban yaitu tanggung jawab secara etika dan tanggungjawab secara hukum.

Pertama, bertanggungjawab secara etika memiliki arti bahwa dalam menjalankan profesinya, PPAT harus memberikan pelayanan kepada masyarakat sebaik mungkin tanpa membedakan jenis pelayanan berdasarkan jumlah pembayarannya. Pelayanan yang diberikan tidak semata-mata bermotif mencari keuntungan, melainkan juga pengabdian kepada masyarakat sebagai makhluk sosial. Dalam organisasi profesi yang dalam hal ini adalah PPAT, terdapat Majelis Kehormatan yang yang mempunyai tugas dan/atau kewajiban untuk melakukan pembinaan, pengawasan dan penertiban maupun pembenahan, serta mempunyai kewenangan untuk memanggil, memeriksa dan menjatuhkan putusan, sanksi atau hukuman kepada anggota perkumpulan Ikatan Pejabat Pembuat Akta Tanah (selanjutnya disingkat IPPAT) yang melakukan pelanggaran Kode Etik. Berkaitan dengan perbuatan seorang PPAT dalam menjalankan tugas dan jabatannya, PPAT bertanggung jawab kepada Majelis Kehormatan IPPAT dalam segala perbuatan yang berkaitan dengan nilai-nilai etika profesi.

Kedua, mengenai tanggung jawab hukum, terdapat dua bentuk pertanggungjawaban yakni pertanggungjawaban perdata serta pertanggungjawaban pidana. Dalam kaitannya dengan kesalahan (beroepsfout) dari PPAT, maka harus ditelaah mengenai bentuk dari kesalahan tersebut, yakni apakah kesalahan tersebut merupakan wanprestasi atau perbuatan melanggar hukum (onrechtmatige daad). Pendapat yang umum dianut bahwa, wanprestasi terjadi apabila didahului dengan adanya perjanjian, sedangkan jika tidak ada kaitannya dengan perjanjian maka bentuk pelanggarannya disebut perbuatan melanggar hukum atau onrechtmatige daaad.

Dalam ranah hukum perdata, Roscoe Pound menyatakan hukum melihat ada 3 pertanggungjawaban atas delik yaitu:

a. Pertanggungjawaban atas perugian yang disengaja;

b. Pertanggungjawaban atas perugian karena kealpaan dan tidak disengaja;

c. Pertanggungjawaban dalam perkara tertentu atas perugian yang dilakukan karena kelalaian serta tidak disengaja.

Berpijak pada prinsip umum tersebut, penulis berpendapat bahwa perbuatan PPAT yang telah menyebabkan sebuah akta peralihan benda tetap atas harta pailit menjadi cacat hukum tidak dapat dianggap sebagai perbuatan melanggar hukum, mengingat jika selama menjalankan jabatannya PPAT telah bertindak sesuai dengan peraturan perundang-undangan serta telah menuangkan isi akta berdasarkan keterangan yang diberikan oleh para pihak. 
Penjatuhan sanksi pidana terhadap PPAT dapat dilakukan sepanjang seorang PPAT telah membuat surat palsu atau memalsukan akta dengan kualifikasi sebagai suatu delik pidana. Syarat materil dan syarat formil dari prosedur pembuatan akta PPAT merupakan aspek-aspek formal yang harus dilalui dalam pembuatan akta jual beli tanah berkaitan dengan tugas jabatan PPAT. Penulis berpendapat bahwa penyimpangan terhadap syarat materil dan syarat formil dari prosedur pembuatan akta PPAT harus dilihat berdasarkan batasan-batasan dari aspek formal yang telah ditentukan oleh peraturan perundang-undangan yang terkait dengan jabatan seorang PPAT.

Adapun aspek-aspek formal dari suatu akta PPAT yang dapat dijadikan dasar atau batasan untuk dapat memidanakan PPAT jika:12

1. Secara sengaja dan terbukti, bahwa dengan insyaf, sadar, dan terencana bahwa ia melakukan suatu tindak pidana menggunakan akta yang dibuatnya;

2. Secara sengaja dan sadar, Pejabat Pembuat Akta Tanah bersama dengan pihak yang berkaitan melakukan suatu tindakan yang merupakan pelanggaran terhadap hukum.

Jika melihat dari Putusan Pengadilan Tingkat Kasasi pada Mahkamah Agung Nomor: 556/Pdt.Sus-Pailit/PKPU/2013 yang telah dijelaskan dalam latar belakang dimana dalam Putusan Pailit tersebut, terdapat upaya pembatalan Penetapan Nomor 44/PKPU/2012/PN. Niaga.Jkt.Pst., tanggal 01 April 2013 dimana penetapan tersebut berisi perubahan hakim pengawas serta dalam penetapan tersebut telah menggabungkan ketentuan Pasal 185 ayat (1) dan ayat (2) Undang-Undang No. 37 Tahun 2004. Selanjutnya proses penjualan benda pailit yang dilakukan oleh Kurator sebelum adanya proses pengajuan pembatalan Penetapan Nomor 44/PKPU/2012/PN. Niaga.Jkt.Pst., tanggal 01 April 2013 tersebut tentunya terdapat peran seorang PPAT dalam penjualan harta tidak bergerak yang termasuk dalam boedel pailit.

Melihat dari contoh kasus diatas, dalam melaksanakan jabatannya PPAT telah bertindak sesuai dengan syarat formiil dan syarat materiil dimana dalam pembuatan Akta Peralihan terhadap benda tetap tersebut, telah dilakukan dengan akta PPAT, sehingga telah memenuhi syarat formil pengalihan hak atas tanah dan memenuhi syarat terang dan nyata. Selanjutnya mengenai syarat materiil Kurator bertindak sebagai penjual berdasarkan ketentuan Pasal 24 ayat (1) Undang-Undang No. 37 Tahun 2004 dimana sejak tanggal putusan pernyataan pailit diucapkan, debitur kehilangan hak untuk menguasai dan mengurus harta kekayaannya yang termasuk dalam harta pailit, dan oleh karena itu kewenangan pengelolaan harta pailit jatuh ke tangan kurator. Sedangkan pihak pembeli juga telah memenuhi syarat sebagai pemilik hak atas benda tetap tersebut.

Berdasarkan penjelasan mengenai syarat formil dan syarat materiil di atas, dapat ditarik kesimpulan bahwa perbuatan PPAT yang berkaitan dengan pembuatan Akta Jual Beli terhadap benda tetap yang termasuk dalam boedel pailit dari kasus di atas adalah sah menurut hukum dan PPAT tidak dapat dikenai sanksi administratif, sanksi pidana, serta sanksi perdata jika dikemudian hari terjadi permasalahan yang menyangkut keabsahan

${ }^{12}$ Habib Adjie, Sanksi Perdata Dan Administrasi Terhadap Notaris Sebagai Pejabat Publik, Cet. Ke-3, Refika Aditama, Bandung, 2013, hlm. 124. 
perjanjian jual beli benda tetap yang termasuk dalam boedel pailit karena PPAT telah melakukan tugasnya sesuai dengan syarat formil dan materiil sebagaimana yang diatur dalam peraturan perundang-undangan yang terkait.

\section{Penutup}

\section{Kesimpulan}

Berdasarkan hasil penelitian ini dapat disimpulkan sebagai berikut:

1. Terjadinya penjualan harta pailit berupa benda tetap oleh kurator kepada pihak ketiga tanpa mekanisme lelang atau secara di bawah tangan karena terdapat berbagai masalah yang timbul dari adanya mekanisme penjualan secara lelang yang menyebabkan terganggunya independensi Kurator diantaranya adalah pertama, proses penjualan secara lelang memakan biaya yang tidak sedikit karena Undang-Undang No. 37 Tahun 2004 tidak membatasi berapa kali proses penjualan secara lelang dapat dilakukan. Kedua appraisal yang dilakukan sebelum penjualan di muka umum sulit dijadikan patokan harga penjualan barang karena perbedaan dengan harga penawaran di lapangan berakibat penjualan harta pailit menjadi tidak optimal. Ketiga peran hakim pengawas hanya menerima laporan penjualan dari kurator yang menyebabkan pasifnya peran Hakim Pengawas. Keempat Putusan yang bermasalah yang menyebabkan perbedaan penafsiran. Selanjutnya Dalil "atau" dalam Penetapan Nomor 44/PKPU/2012/PN.Niaga.Jkt.Pst., tanggal 01 April 2013 memberikan peluang bagi kurator untuk melakukan penjualan terhadap boedel debitor pailit tanpa mekanisme lelang terlebih dahulu ditambah berbagai permasalahan di atas memungkinkan Kurator untuk memilih mekanisme penjualan secara di bawah tangan atas boedel pailit debitor dibanding dengan penjualan harta pailit secara di muka umum (lelang).

2. Tanggungjawab PPAT apabila dikaitkan dengan profesinya menganut prinsip tanggungjawab kesalahan (based on fault of liability). Sehingga dalam pembuatan akta otentik, PPAT harus bertanggungjawab apabila terjadi kesalahan atau pelanggaran terhadap akta yang dibuatnya. Tanggungjawab yang dimiliki oleh PPAT berkaitan dengan isu hukum Putusan Pengadilan Tingkat Kasasi pada Mahkamah Agung Nomor: 556/Pdt.Sus-Pailit/PKPU/2013 dalam perannya sebagai syarat formil dari perjanjian jual beli terhadap harta pailit berupa benda tetap diantaranya adalah tanggung jawab secara Etika dan tanggung jawab secara hukum. Tanggungjawab secara perdata tidak dapat dibebankan kepada PPAT karena dalam pelaksanaan jabatannya PPAT tidak terbukti secara sah oleh Pengadilan melakukan suatu perbuatan melawan hukum yang menimbulkan kerugian bagi para pihak, selanjutnya tanggungjawab PPAT secara pidana melalui mekanisme pengadilan berkaitan dengan isu hukum diatas adalah bahwa PPAT tersebut tidak terbukti melakukan suatu tindak pidana menggunakan akta yang dibuatnya dan/atau perbuatan PPAT tersebut bersama dengan pihak yang berkaitan tidak melakukan suatu tindakan yang merupakan pelanggaran terhadap hukum. 


\section{Saran}

Berdasarkan kesimpulan di atas, maka saran yang diberikan oleh penulis adalah sebagai berikut:

1. Hendaknya Pengadilan Niaga mengatur peningkatan peran hakim pengawas dalam proses penjualan harta pailit, sehingga nantinya peran hakim pengawas dapat memaksimalkan proses penjualan harta pailit yang tidak merugikan Debitor maupun Kreditor

2. Evaluasi dan deregulasi terkait penentuan nilai limit objek hak tanggungan oleh appraiser selaku penilai perlu di perhatikan seksama. Dengan mengikutsertakan debitor dalam hal penentuan nilai limit objek lelang dan memberitahukan harga dan waktu lelang kepada debitur sebelum objek dilelang di KPKNL, diharapkan akan berdampak besar bagi debitor yang merupakan pihak yang memiliki posisi tawar yang lemah, sehinggal hasil jual objek lelang dapat bernilai maksimal bagi Debitor maupun Kreditor.

3. Hendaknya Pemerintah menekankan fungsi pembinaan dan pengawasan oleh organisasi profesi dalam Undang-Undang Nomor 37 Tahun 2004.

\section{Daftar Pustaka}

\section{Buku}

Adjie, Habib, Sanksi Perdata Dan Administrasi Terhadap Notaris Sebagai Pejabat Publik, Cetakan Ke-3, Refika Aditama, Bandung, 2013.

Hakim, Abdul G. Nusantara, Politik Hukum Indonesia, Yayasan Lbh Indonesia, Jakarta, 1998.

Rahardjo, Satjipto, Ilmu Hukum, Cetakan Ke-7, Citra Aditya Bakti, Bandung, 2012.

Dewi Amrih Suci, Ivida Dan Herowati Poesoko, Hukum Kepailitan, Kedudukan Kreditor Separatis Atas Benda Jaminan Debitor Pailit, Laksbang Pressindo, Yogyakarta, 2016.

S. Sastrawidjaja, Man, Hukum Kepailitan Dan Penundaan Kewajiban Pembayaran Utang, Alumni, Bandung, 2006.

Asikin, Zainal, Hukum Kepailitan Dan Penundaan Pembayaran Di Indonesia, Raja Grafindo Persada, Jakarta, 2001.

\section{Hasil Penelitian/Tugas Akhir}

Faiz Nasrulloh, Mohamad, Perlindungan Hukum Bagi Debitur Dalam Penentuan Harga Obyek Lelang Sepihak Yang Dilaksanakan Di Kantor Pelayanan Kekayaan Negara Dan Lelang (KPKNL) Kota Semarang, Skipsi: Fakultas Syariah Dan Hukum Universitas Islam Negeri Walisongo Semarang, 2020.

\section{Jurnal}

Febryka Nola, Luthvi, Mafia Kepailitan Dalam Penjualan Harta Pailit, Jurnal Kajian Vol. 23 No. 3 September 2018, Pusat Penelitian Badan Keahlian DPR RI.

\section{Peraturan Perundang-undangan}

Undang-Undang Nomor 37 Tahun 2004 tentang Kepailitan Dan Penundaan Kewajiban Pembayaran Utang

Peraturan Pemerintah Nomor 24 Tahun 1997 tentang Pendaftaran Tanah. 